\title{
Clinical Characteristics and Long-Term Outcomes of Systemic Lupus Erythematosus in Children
}

\author{
Çocuklarda Sistemik Lupus Eritematozusun Klinik Özellikleri ve Uzun Dönem \\ Sonuçları
}

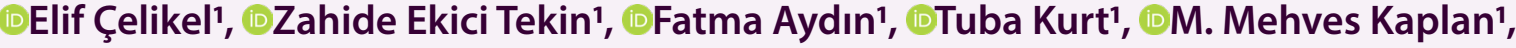 \\ Cuneyt Karagöl', @Muge Sezer', @Nilufer Tekgöz'1, @Serkan Coskun'1, \\ Banu Çelikel Acar', $₫$ Nilgun Cakar²
}

'Ankara City Hospital, Department of Pediatrics, Division of Pediatric Rheumatology, Ankara, Turkey

${ }^{2}$ Ankara University Faculty of Medicine, Department of Pediatric Rheumatology, Ankara, Turkey

\begin{abstract}
Aim: Systemic lupus erythematosus (SLE) is a common multisystemic autoimmune disease characterized by the presence of autoantibodies and multiorgan system involvement. The aim of this study was to describe the presenting clinical manifestations, laboratuary findings, clinical course and prognosis of SLE in children.
\end{abstract}

Material and Method: We performed a retrospective study patients with SLE, diagnosed before the age of 18 years. Clinical and laboratory data were collected from initial admission to study initiation.

Results: Thirty-five children and adolescents SLE (CSLE) were recorded, $85.7 \%$ of female. The median age at disease onset was 12(range 4-17) years, and median follow up duration was 5 (114) years. The most common clinical feature was arthritis (65.1\%), followed by constitutional symptoms $(48.6 \%)$, malar rash (31.4\%), photosensitivity (5.7\%), alopecia $(5.7 \%)$ and oral ulcers (5.7\%). Renal involvement accounted $4 / 5$ of the patients (80\%). Hematuria and proteinuria were the most frequent presenting findings (48.5\% and $45.7 \%$ respectively). Renal biopsy was performed in 27 patients. According to WHO classification: 1 patient had classV nephritis, 10 had class IV, 4 had class III and 12 had class II nephritis. $20 \%$ of children developed neurologic symptoms. One patient died during the follow-up period. At the last follow up none of the patients had renal failure but, proteinuria persisted in 4 of them (11.4\%). All neurological findings of patients are in remission apart from sequelae.

Conclusion: Clinical outcome was favorable in our patients. Renal involvement is common but progression to end stage kidney disease, at least in the short term, is rare.

Keywords: Children, initial presentation, prognosis, systemic lupus erythematosus

\section{ÖZ}

Amaç: Sistemik lupus eritematozus (SLE), otoantikorların varlığı ve çoklu organ sistemi tutulumu ile karakterize, yaygın bir multisistemik otoimmün hastalıktır. Bu çalışmanın amacı, çocuklarda SLE'nin klinik belirtilerini, laboratuvar bulguları, klinik seyrini ve prognozunu tanımlamaktır.

Gereç ve Yöntem: 18 yaşından önce tanı almış SLE'li hastaları retrospektif olarak incelendi.. Klinik ve laboratuvar verileri, ilk kabulden çalışmanın başlamasına kadar geçen sürede hastaların klinik ve laboratuvar verileri kaydedildi.

Bulgular: Otuz beş çocuk ve adölesan SLE (cSLE) hastanın \%85,7'si kadındı. Ortalama hastalık başlangıç yaşı 12 (4-17 arası) yıl ve medyan takip süresi 5 (1-14) yıldı. En sık görülen klinik özellik artrit $(\% 65,1)$ idi, bunu konstitusyonel semptomlar $(\% 48,6)$, malar döküntü $(\% 31,4)$, ışığa duyarlılık $(\% 5.7)$, alopesi $(\% 5,7)$ ve oral ülserler $(\% 5,7)$ izliyordu. Böbrek tutulumu hastaların 4/5'ini (\%80) oluşturuyordu. Hematüri ve proteinüri en sık başvuru bulgusuydu (sırasıyla \%48,5 ve \%45,7). 27 hastaya böbrek biyopsisi yapıldı. WHO sınıflamasına göre: 1 hastada sınıf V, 10 hastada sınıf IV, 4 hastada sınıf III ve 12 hastada sınıf II nefrit vardı. Çocukların \%20 'sinde nörolojik semptomlar gelişti. Takip süresi boyunca bir hasta öldü. Son takipte hiçbir hastada böbrek yetmezliği gelişmedi, ancak 4'ünde $(\% 11,4)$ proteinüri devam etti. Hastaların sekel dışında tüm nörolojik bulguları remisyondadır.

Sonuç: Hastalarımızda klinik sonuç olumluydu. Böbrek tutulumu yaygındır, ancak en azından kısa vadede son dönem böbrek hastalığına ilerleme nadirdir.

Anahtar Kelimeler: Çocuklar, ilk başvuru, prognoz, sistemik lupus eritematozus 


\section{INTRODUCTION}

Systemic lupus erythematosus (SLE) is a complex systemic autoimmune disease characterized by the presence of autoantibodies and multiorgan system involvement. Approximately $15-20 \%$ of patients present in the first two decades of life (1). It is the most common rheumatic disease associated with morbidity and mortality in children. Although the specific cause of SLE is unknown, genetic and environmental factors are involved in the pathogenesis. The disease is characterized by immune dysregulation involving both the innate and adaptive immune systems with polyclonal B-cell activation, which results in the production of selfreactive autoantibodies (2).

The clinical presentation at onset of SLE is heterogeneous; it may range from rash and arthritis to severe lifethreatening multi-organ involvement. Childhood-onset SLE (cSLE) are known to have a more severe course with higher prevalence of renal and neuropsychiatric manifestations. In addition, cSLE is often more acute and severe, affecting multiple organs in children compared to adults. Therapeutic approaches involve immunosuppression and immunomodulation and are tailored to the severity of disease and the extent of organ damage (3). The aim of treatment is to target specific organ manifestation in order to achieve low disease activity.

Because of the different presentations, manifestations, and laboratory abnormalities in patients with CSLE, diagnosis can be challenging. The aim of this study was to describe the presenting clinical manifestations, laboratory findings, clinical course and prognosis of cSLE.

\section{MATERIAL AND METHOD}

This study was conducted with a retrospective review of the medical records of 35 SLE patients who were followed regularly in a tertiary referral hospital between January 1995 and December 2017. Inclusion criteria were: Fulfillment of the revised American College of Rheumatology (ACR) 1982 criteria for diagnosing SLE (4), age of onset of symptoms $<18$ years. The inclusion criteria were: fulfillment of revised American College of Rheumatology (ACR) 1982 criteria for diagnosis of SLE (4) , age at onset of symptoms at less than 18 years of age. Patients with missing data and who were followed up for less than six months were excluded from the study.

All patients were systematically reviewed for: demographic characteristics, age at disease onset, disease duration, follow-up duration, clinical features and laboratory variables as well as the treatment and outcomes. Clinical manifestations such as skin rashes, a fever above $38^{\circ} \mathrm{C}$, photosensitivity, ulcers, arthritis/ arthralgia, serositis, nephritis (defined as mesangial, focal proliferative, diffuse proliferative or membranous glomerulonephritis according to the WHO (World Health Organisation) classification on histopathology, or persistent proteinuria of $>0.5 \mathrm{~g} /$ day, proteinuria of $>3.5$ $\mathrm{g} /$ day, or cellular casts of any kind according to the ACR criteria) were recorded. Laboratory findings included urinary testing (with abnormalities defined as any one of the following: urinary casts, hematuria ( $>5$ red blood cells/high power field), proteinuria $(\geq 1+)$, pyuria $(>5$ white blood cells/high power field), complete blood and differential counts, erythrocyte sedimentation rate (ESR), serum C3 and C4 levels, antinuclear antibodies (ANA), anti-cardiolipin $(\mathrm{aCL}) \mathrm{lgG} / \mathrm{M}$ testing and double-stranded DNA (ds-DNA) antibody were recorded. Antinuclear antibodies and anti-dsDNA were determined by indirect immunofluorescence or enzyme-linked immunosorbent. Serum C3 and C4 were measured by immunodiffusion or turbidimetric immunoassay.

Data on induction and maintenance therapy were collected. Patients with WHO Class II LN were treated with combinations of tapering doses of oral prednisone and/ or azathioprine (AZA) depending on extra-renal disease. Patients with proliferative nephritis (WHO Class III and IV $\mathrm{LN})$ were treated with intravenous methylprednisolone (30 $\mathrm{mg} / \mathrm{kg}$ ) pulse followed by $2 \mathrm{mg} / \mathrm{kg}$ /day (max 60 $\mathrm{mg}$ ) oral prednisolon at the first month of therapy, and gradually tapered along with monthly intravenous cyclophosphamide (CYP) infusions for the first six months, followed by maintenance with either three monthly CYP infusions for 18 to 24 months or AZA (2-2.5 mg/kg/day) and low-dose oral prednisone. mycophenolate mofetil (MMF) was used both for induction and maintenance therapy in association with oral prednisone in a few patients. A minority of patients with refractory disease were treated with rituximab. Angiotensin-converting enzyme inhibitors (ACEls) and/or angiotensinreceptor blockers (ARBs) were used in most patients for hypertension and/or proteinuria. Anticoagulants were used in patients with secondary antiphospholipid syndrome if indicated. Hydroxychloroquine was used both for the relief of joint and skin manifestations, and also to prevent flares of the disease.

The study was approved by the ethical committee of Ankara City Hospital (E2-21-532). All procedures were carried out in accordance with the ethical rules and the principles of the Declaration of Helsinki.

\section{Statistical Analysis}

Descriptive statistical analysis methods were used to evaluate the demographics and clinical data. The mean, median, standard deviation, range were calculated. Frequency tables were used to describe the categorical data. Data were analyzed using SPSS v.21 (SPSS Inc., Chicago, IL, USA). 


\section{RESULTS}

This study consisted of 35 (30 female, female to male ratio was 6:1) patients with cSLE. The median age at disease onset was 12 (4-17) years. Only one child was below five years of age at diagnosis. At the time of diagnosis, 18 of patients ages were over 17 and 18 of them were girl. The median duration of follow-up was 5 (1-14) years. The follow up time was more than two years in 29/35 patients, while it was longer than five years in $21 / 35$ of them.

The most common extrarenal clinical feature was nondeforming arthritis (65.1\%), followed by, constitutional symptoms $(48,6 \%)$ such as fever, fatigue and anorexia. The malar rash (31.4\%) was the most common cutaneous manifestation followed by photosensitivity (8.6\%) and alopecia (5.7\%). Serositis was found in $17.1 \%$ of the patients.

\section{Renal Involvement}

Approximately $4 / 5$ patients (80\%) had renal involvement. Eighty-three percent of females and $100 \%$ of males had renal disease at diagnosis.

Hematuria and proteinuria were the most common presenting findings ( $48.5 \%$ and $45.7 \%$ respectively) of renal involvement. Seven patients (20\%) had nephrotic syndrome. Three patients presented with nephritic features (hypertension and gross hematuria). Three patients had renal impairment at presentation (one Class IV nephritis, two Class II nephritis).

Table 1 summarizes the clinical and laboratory features of the patients at disease onset.

Renal biopsy was performed in 27 patients. According to WHO classification: 1 patients had class $V$ nephritis, 10 had class IV, 4 had class III and 12 had class II nephritis. The renal findings of patients biopsied are given in Table $\mathbf{2}$.

\section{Neurological Involvement}

Neurological involvement (NP-SLE) was seen in seven patients (20\%); 3 patients had headache, 2 had chorea, 1 had acute confusional state and 1 had seizure. Median age of these patients was 13 years.

During the treatment, psychosis developed in one patient. Her symptoms were not accompanied with flaring in immunological parameters and primary illness (lupus nephritis). She was managed symptomatically with antipsychotics and reduced steroid dosage.

\section{Hematological and Immunological Findings}

Hematological abnormalities were revealed in 21 patients $(60 \%)$ at the time of diagnosis. Anemia was the most common hematological manifestations at onset (74\%). Hemolytic anemia with positive Coomb's test was detected in 13 patients (37.1\%). Twelve patients had leucopenia (34.3\%), and 15 patients (42.9\%) had thrombocytopenia.

\begin{tabular}{|c|c|}
\hline Characteristics & n (\%) \\
\hline \multicolumn{2}{|l|}{ Demographic data } \\
\hline Age at diagnosis, median (range) years & $12(4-17)$ \\
\hline Follow-up duration, median (range) years & $5(1-14)$ \\
\hline Female/Male & $30 / 5(6 / 1)$ \\
\hline Fever, fatigue, anorexia & $17(48.6 \%)$ \\
\hline \multicolumn{2}{|l|}{ Cutaneous findings } \\
\hline Malar rash & $11(31.4 \%)$ \\
\hline Photosensitivity & $3(8.6 \%)$ \\
\hline Alopecia & $2(5.7 \%)$ \\
\hline Oral ulcers & $2(5.7 \%)$ \\
\hline Weight loss & $2(5.7 \%)$ \\
\hline Arthritis-arthralgia & $23(65,1 \%)$ \\
\hline Serositis & $6(17.1 \%)$ \\
\hline Pericardial & $4(11.4 \%)$ \\
\hline Pleural & $2(5.7 \%)$ \\
\hline Renal involvement & $28(80 \%)$ \\
\hline Nervous system involvement & $7(20 \%)$ \\
\hline Hematological and immunological involvement & $21(60 \%)$ \\
\hline Cardiovascular involvement & $6(17.1 \%)$ \\
\hline
\end{tabular}

Table 2. Renal biopsy findings as per WHO classification among patients who had undergone a kidney biopsy in our series of pediatric SLE patients $(n=27)$

\begin{tabular}{|c|c|c|c|}
\hline Histopathology & $\begin{array}{c}\text { Number of patients } \\
\text { n (\%) }\end{array}$ & $\begin{array}{c}\text { Follow up (at the end of } \\
\text { the first year) }\end{array}$ & $\begin{array}{c}\text { Follow up (at the end of the } \\
\text { five years) }\end{array}$ \\
\hline Minimal mesangial lupus nephritis (Class I) & 0 & & \\
\hline Mesangial proliferative lupus nephritis (Class II) & 12 (44.4\%) & $\begin{array}{c}11 \text { normal } \\
1 \text { nephritic proteinuria }\end{array}$ & $\begin{array}{l}8 \text { normal } \\
1 \text { nephritic proteinuria (Class III)* } \\
1 \text { nephrotic syndrome (Class IV)* }\end{array}$ \\
\hline Focal lupus nephritis (Class III) & $4(14.8 \%)$ & $\begin{array}{c}3 \text { normal } \\
1 \text { nephritic proteinuria }\end{array}$ & 4 normal \\
\hline Diffuse lupus nephritis (Class IV) & $10(37.0 \%)$ & $\begin{array}{c}6 \text { normal } \\
3 \text { nephritic proteinuria } \\
1 \text { nephrotic syndrome }\end{array}$ & $\begin{array}{c}4 \text { normal } \\
2 \text { nephritic proteinuria } \\
2 \text { nephrotic syndrome (Class IV)* }\end{array}$ \\
\hline Membranous lupus nephritis (Class V) & $1(3.7 \%)$ & 1 normal & \\
\hline Advanced sclerosing lupus nephritis (Class VI) & 0 & & \\
\hline
\end{tabular}


One patient presented with microangiopathic hemolytic anemia (MAHA), one with macrophage activation syndrome; a 15-years old male patient presented with microangiopathic hemolytic anemia and nephritic syndrome. He had thrombocytopenia $\left(45,000 / \mathrm{mm}^{3}\right)$, schistocytes and fragmanted erythrocytes on blood smear, elevated LDH (2255 IU, $\mathrm{N}: 0-248 \mathrm{IU} / \mathrm{L}$ ), blood urea and creatinine (urea $69 \mathrm{mg} /$ $\mathrm{dL}$, creatinin 1,22 $\mathrm{mg} / \mathrm{dL}$ ), hypocomplementemia and elevated ANA, antids-DNA titer. Renal biopsy showed Class II lupus nephritis.

A 13years old girl presented with macrophage activation syndrome. She has neither hypocomplementemia nor renal involvement but severe cutaneous erythema, vasculitis and onycomycosis. ANA and antidsDNA were strong positive. C1q deficiency was detected. She was treated with pulse methylprednisolon and cyclosporine at the acute attack then therapy continued with azathioprin and oral prednisolon. Two years later azathioprin switched to (MMF) because of the severe neutropenia. One year later, at the second attack of macrophage activation syndrome she died.

ANA positivity was detected in 32 patients (91.44\%) and $88.6 \%$ of them had elevated anti-dsDNA titer. Low serum C3 levels were found in $24(68.6 \%)$, low serum C4 levels were found in 27 (77.1\%) patients $(66.4 \pm 40,1$ $\mathrm{mg} / \mathrm{dL} ; 12.5 \pm 8,09 \mathrm{mg} / \mathrm{dL}$ respectively).

Anticardiolipin antibodies ( $\mathrm{aCL}$ ) were positive 10 of the 35 patients. aCL was positive in $5(71.4 \%)$ of 7 NP-SLE patients, while $5(17.8 \%)$ of 28 non NP-SLE patients. Antiphospholipid syndrome (APLAS) developed in two patients. One of them had presented with catastrophic APLAS (seizure, necrotizing pancreatitis, unilateral renal artery thrombosis), the other patient presented with digital ulcers.

\section{Treatment}

All patients with class IV nephritis were treated with pulse metilyprednisolon and intravenous CYP for six months as an induction therapy then shifted to either azathioprine (6 patients) or mycofenolate mofetil (4 patients). All patients received hydroxychloroquin during follow up.

\section{Prognosis}

One patient died during the follow-up period from macrophage activation syndrome. At the last follow up none of them had renal failure but, proteinuria persisted in 4 of them (11.4\%). Five of the 7 patients with neurological findings (71.4\%) completely recovered, and two patients had longterm neurological complications, including one with cognitive impairment and a hemiplegic gait and one with visual impairment.

\section{DISCUSSION}

Childhood-onset systemic lupus erythematosus is a chronic, potentially fatal autoimmune disease with a great variability in disease presentation and course. In this study we described the characteristics of 35 children with cSLE seen in a tertiary referral hospital. Our report suggests that female gender was predominant and constitutional symptoms are the most common features at presentation. The current study showed that most cases of cSLE appeared after the pubertal period ( $>12$ years of age). It might be explained by the hormonal effects on SLE patients after puberty has been also observed in most studies (5).

The presentation, clinical manifestations, immunological findings and treatment issues of CSLE are similar to those of adult SLE patients (6). On the other hand, pediatric and adult SLE differ in multiple aspects, and it is important to recognize these differences for optimal treatment and prognosis of these patients. In general, children with SLE tend to have a more severe disease at onset with higher rates of organ involvement and a more aggressive clinical course than adult-onset SLE patients $(7,8)$. In the first year of diagnosis, 35$90 \%$ of children will present with constitutional and generalized symptoms, $20-80 \%$ will have nephritis, 20-74\% musculoskeletal symptoms, $60-80 \%$ any skin involvement, 15-30\% neuropsychiatric disease, 5-30\% cardiovascular disease, and $18-40 \%$ pulmonary disease (2).

The arthritis of SLE is typically non-erosive and nondeforming and involves larger joints such as knees, ankles, wrists and small joints of hands and feet. Arthralgia and arthritis were noted in $65.1 \%$ of our patients.

As expected, renal involvement accounted $4 / 5$ of our patients (80\%). Approximately $45 \%$ of patients had hematuria and proteinuria and $20 \%$ of patients had nephrotic syndrome at baseline. Renal impairment was seen in three patients at presentation. Ten patients had class IV nephritis according to WHO classification. Although renal involvement at the time of disease onset were associated with worse outcome, at the last follow up none of them had renal failure but, proteinuria persisted in $11.4 \%$ of them. A number of studies, but not all, have reported that the predominant clinical features of patients with Class IV, include hypertension, impaired kidney function, anemia, proteinuria, hypocomplementemia, and high anti-dsDNA titer ( 9 , 10). Inconsistency in these results could be related to variations in the genetics, demographic area, and/or ethnicity of the study populations. Recently Srivastava et al. reported the renal outcome of 205 cSLE patients, revealing $46.7 \%$ Class IV nephritis. In this study renal survival at five, 10 and 15 years was 93.8\%, 87.1\% and $84 \%$, respectively (11). Although multiple factors 
individually predicted poor outcome, only raised serum creatinine at onset and damage accrual remained significant. In our series a transient elevation of serum creatinine was observed in three patients, and renal survive was found in $100 \%$ after a median follow up of five years.

Neuropsychiatric (NP) manifestations are found in approximately 25 to $90 \%$ of children and adolescent patients with SLE. Nearly half of the NP involvement will occur within the first year from the time of diagnosis. Headaches are common (50-75\%), but true lupus headache is considered to be associated with significant intracranial pathology including cerebrovascular disease such as vasculitis and cerebral vein thrombosis. Following headache, psychiatric manifestations of pSLE are the most common NP manifestation. This may occur as part of the primary disease process, or secondary to central nervous system sequelae of SLE, e.g. seizures, infection or adverse effect of treatment with steroids, or immunosuppressant (12). Cerebrovascular disease, seizures and chorea are seen in about 25\%, 20\% and $5 \%$ of NP-pSLE patients respectively . In our study NPSLE was seen in seven patients (20\%); 3 patients had headache, 2 had chorea, 1 had acute confusional state and 1 had seizure.

Involvement of peripheral nervous system and the CNS has been reported to occur in 20\% to $95 \%$ of patients with cSLE. Neuropsychiatric symptoms in children with SLE cause high morbidity and disability. The majority of patients with NP-SLE have the initial signs and symptoms within the first year of diagnosis of SLE; approximately $25 \%$ initially develop NP-SLE more than 2 years after disease onset (2). Neuropsychiatric involvement may result in more damage and poorer outcome (13) . Various autoantibodies have been implicated in the pathogenesis of NP-SLE, including antiribosomal $P$ protein, antineuronal, antiganglioside, antiphospholipid (aPL), and antiendothelial antibodies (14-16). One of the most intriguing issues is the association of neuropsychiatric manifestations with aPL. These autoantibodies can lead to thrombosis of cerebral vessels, both arterial and venous and a nonthrombotic, immune-mediated neurologic impairment has been associated with aPL. The risk of NPSLE is three times greater in children with systemic lupus erythematosus and a positive lupus anticoagulant which are also specific risk factors for stroke in children and adults (17). In our study, tests for aCL were carried out 10 of 35 patients with SLE and 5 (71.4\%) of 7 patients with NP-SLE.

Zuniga et al. defined seizures, migraine and depression as the most common NP symptoms in 30 of $90 \mathrm{cSLE}$ patients (18) . Lupus anticoagulant (LAC) was found positive in high titers in these patients, and they proposed that immunesupressive treatment could avert or delay NP symptoms. Avcin et al. also found a persistently positive aCL in $50 \%$, anti- $\beta 2 \mathrm{GPI}$ in $29 \%$, and LAC in $16 \%$ of children with SLE (19). They found that the prevalence of anti- $\beta 2 \mathrm{GPI}$ antibodies was found to be higher in the group of SLE patients with neuropsychiatric disease compared with those without. Their study suggested an association between LAC and cerebrovascular disease at the time of SLE diagnosis and chorea over the disease course, but not between aPL and other neuropsychiatric manifestations (20) .

Recent cSLE studies have shown 5-year survival rates of $>95 \%$, with 10-year survival rates reported to be as high as $86 \%$. Mortality rates have been shown to be associated with socioeconomic status and individual access to health care, educational background, racial/ethnic background, endemic infection rates, disease activity, and renal or central nervous system involvement (20). Common causes of death within the first 2 years are pancreatitis, pulmonary hemorrhage, infection, thromboembolic disease, and active neuropsychiatric disease. The causes of late death $(>5$ years) are complications of end-stage renal disease, atherosclerosis, suicide, and less commonly active SLE or infection (21). Singh et al. performed a renal biopsy in 53 of 72 cSLE patients and observed Class IV nephritis in 35 . Mortality occurred in 22 children (30\%), with half of these occurring at presentation. The two important causes of death were infection and end-stage renal disease (22). In our series of 35 children only one patient died from macrophage activation syndrome.

\section{CONCLUSION}

The current study provides longterm outcome of LN in cSLE. Long-term patient and renal survival rates in our series are favorable. Children with cSLE and having $\mathrm{aCL}$ positivity should be followed closely for NP symptoms.

\section{ETHICAL DECLARATIONS}

Ethics Committee Approval: This study was approved by the the Ethics Committee of Ankara City Hospital (E221-532).

Informed Consent: All patients signed the free and informed consent form.

Referee Evaluation Process: External double-blind referee assessment.

Conflict of Interest Situation: The authors have no conflicts of interest to declare.

Financial Disclosure: This research didn't receive grants from any funding agency in the public, commercial or not-for-profit sectors.

Author Contributions: All of the authors; the design of the article, participated in the execution, analysis and final version. They declared that they approved. 


\section{REFERENCES}

1. Malleson PN, Fung MY, Rosenberg AM. The incidence of pediatric rheumatic disease:results from the Canadian pediatric Rheumatology Association Disease Registry. J Rheumatol 1996;23(11):1981-7.

2. Levy DM, Kamphuis S. Systemic lupus erythematosus in children and adolescents. Pediatr Clin North Am. 2012;59(2):345-64.

3. Pan L, Lu MP, Wang JH, et al. Immunological pathogenesis and treatment of systemic lupus erythematosus. World J Pediatr. 2020;16(1):19-30.

4. Tan EM, Cohen AS, Fries JF, et al. The 1982 revised criteria for the classification of the systemic lupus erythematosus. Artrhritis Rheumatol 1982;25(11):1271-7.

5. Charras A, Smith E, Hedrich CM. Systemic Lupus Erythematosus in Children and Young People. Curr Rheumatol Rep. 2021;23 (3):20.

6. Klein-Gitelman M. Pediatric lupus versus adult lupus role of the laboratory. Clin Appl Immunol Rev.2004;4:333-50.

7. Brunner HI, Gladman DD, Ibanez D, et al. Difference in disease features between childhood-onset and adult-onset systemic lupus erythematosus. Arthritis Rheum 2008;58(2):556-62.

8. Wang LC, Yang YH, Lu MY, et al. Retrospective analysis of mortality and morbidity of pediatric systemic lupus erythematosus in the past two decades. J Microbiol Immunol Infect 2003;36:203-8.

9. Oni L, Wright RD, Marks S, et al. Kidney outcomes for children with lupus nephritis. Pediatr Nephrol. 2021;36(3):1377-85.

10. Hill GS, Delahousse M, Nochy D, et al. Class IV-S versus class IV-G lupus nephritis:clinical and morphologic differences suggesting different pathogenesis. Kidney Int 2005;68(5):2288-97.

11. Srivastava $P, A b u j a m ~ B$, Misra R, et al. Outcome of lupus nephritis in childhood onset SLE in North and Central India:single-centre experience over 25 years. Lupus. 2016;25(5):547-57.

12. Sibbitt $W L$, Brandt $J R$, Johnson $C R$, et al. The incidence and prevalence of neuropsychiatric syndromes in pediatric onset systemic lupus erythematosus. The Journal of Rheumatology 2002;29(7):1536-42.

13. Spinosa MJ, Bandeira $M$, Liberalesso $P B$, et al. Clinical, laboratory and neuroimage findings in juvenile systemic lupus erythematosus presenting involvement of the nervous system. Arq Neuropsiquiatr 2007;65(2B):433-9.

14. Greenwood DL, Gitlits VM, Alderuccio F, et al. Autoantibodies in neuropsychiatric lupus. Autoimmunity 2002;35(2):79-86.

15. Akca UK, Ayaz NA. Comorbidities of antiphospholipid syndrome and systemic lupus erythematosus in children. Curr Rheumato Rep. 2020;22(6):21.

16. Steens SC, Bosma GP, Steup-Beekman GM, et al. Association between microscopic brain damage as indicated by magnetization transfer imaging and anticardiolipin antibodies in neuropsychiatric lupus. Arthritis Res Ther 2006; 8(2): R38.

17. Singh S, Gupta MK, Ahluwalia J, et al. Neuropsychiatric manifestations and antiphospholipid antibodies in pediatric onset lupus: 14 years of experience from a tertiary center of North India. Rheumatol Int. 2009;29(12):1455-61.

18. Zuniga Zambrano YC, Guevara Ramos JD, Penagos Vargas NE, et al. Risk factors for neuropsychiatric manifestations in children with systemic lupus erythematosus:case- control study. Pediatr Neurol. 2014;51(3):403-9.

19. Avcin T, Benseler SM, Tyrrell PN, et al. A follow-up study of antiphospholipid antibodies and associated neuropsychiatric manifestation in 137 children with systemic lupus erythematosus. Arthritis Rheum. 2008;59(2):206-13.

20. Miettunen PM, Ortiz-Alvarez RE, Petty RE, et al. Gender and ethnic origin have no effect on longterm of childhood-onset systemic lupus erythematosus. J Rheumatol. 2004;31(8):1650-4.

21. Wang LC, Yang YH, Lu MY, et al. Retrospective analysis of mortality and morbidity of pediatric systemic lupus erythematosus in the past two decades. J Microbiol Immunol Infect. 2003;36(3):203-8. 